\section{Change in the Bound Ascorbic Acid Content of Muscle and Liver of Rat in Relation to Age}

Changes in the composition of cells of different tissues in relation to age may result in alterations of the enzyme activities and metabolic rate which ultimately regulate the function of the cell. The study of chemical changes has therefore a basic association with the ageing of various tissues. The fact that ageing is accompanied by concomitant loss of functional cells has attracted the attention of various workers ${ }^{1}$. The nitrogen, potassium and phosphorus contents of rat skeletal muscle, a fixed postmitotic tissue, decreased significantly with age when compared with those of liver, a mitotic potential tissue ${ }^{2}$. No significant change was found in the activity of DNA and various other enzymes of the liver when fully matured rats were compared with old rats ${ }^{3}$. Ascorbic acid is known to participate in various metabolic functions ${ }^{4}$, and these specifie functions indicate that it may play some important part in the ageing process ${ }^{4-6}$. Bound ascorbic acid has been shown to have an enzyme function?. In the present investigation the content of bound ascorbic acid in liver and muscle has been estimated to evaluate the effect of age.

Female albino rats aged 30 and 99 weeks were maintained as previously described. Total skeletal muscle from the hip to the hind limb of the left side was cleansed of adherent fats and used to estimate bound ascorbic acid, dry weight and DNA content. The liver was cleansed of adherent tissue and the same factors determined. The bound ascorbic acid was estimated by the method of Summerwell and Sealock ${ }^{7}$ as modified by Patnaik and $\mathrm{Kanungo}^{6}$; the dry weight was estimated after the tissue had been heated in an oven at $110^{\circ} \mathrm{C}$ for $24 \mathrm{~h}$, and the method of Schneider ${ }^{8}$ was used to estimate DNA. Optical densities were measured in a Beckman spectrophotometer. The results were expressed on the basis of wet weight, dry weight and DNA content of tissue and the statistical unalysis was carried out by the methend of Garret ${ }^{3}$.

Table 1. BOUND ASCORBIC ACID IN THE MUSClE AND LIVER OF RAT

\begin{tabular}{|c|c|c|c|c|}
\hline Tissue & $\begin{array}{c}\text { Age } \\
\text { (weeks) }\end{array}$ & $\begin{array}{l}\text { Mg of ascorbic } \\
\text { acid/100 g wet } \\
\text { weight } \pm S . E . M .\end{array}$ & $\begin{array}{c}\text { Mg of ascorbic } \\
\text { acid/100 g dry } \\
\text { weight } \pm S . E . M .\end{array}$ & $\begin{array}{l}\text { Mg of ascorbic } \\
\text { acid/mg DNA } \\
\pm S . E . M .\end{array}$ \\
\hline Muscle & $\begin{array}{l}30 \\
99\end{array}$ & 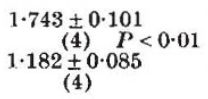 & $\begin{array}{c}7 \cdot 912 \pm 0 \cdot 291 \\
\left(\frac{4}{4}\right) P<0.01 \\
4.804 \pm 0.342 \\
(4)\end{array}$ & $\begin{array}{c}0 \cdot 496 \pm 0 \cdot 028 \\
(4) \quad P>0 \cdot 20 \\
0 \cdot 476 \pm 0.040 \\
(4)\end{array}$ \\
\hline Liver & $\begin{array}{l}30 \\
99\end{array}$ & $\begin{array}{c}4.665 \pm 0.325 \\
(4) P<0.02 \\
3 \cdot 236 \pm 0.237 \\
(3)\end{array}$ & $\begin{array}{c}15 \cdot 704+1 \cdot 037 \\
211.507 \pm \frac{P}{(5)}<0.230 \\
(3)\end{array}$ & $\begin{array}{c}0 \cdot 186 \pm 0.010 \\
(4) \quad P<0.05 \\
0 \cdot 133 \pm 0.015 \\
(3)\end{array}$ \\
\hline
\end{tabular}

Numbers in parentheses indicate animals killed.

In both muscle and liver the concentration of bound ascorbic acid decreased with age when the results were expressed on the basis of three parameters. The changes expressed on the basis of DNA content, however, were not very significant either in muscle $(P>0 \cdot 20)$ or liver $(P<0 \cdot 05)$. If the DNA content of a tissue is relative to the cell number, then the trend of a change in chemical constituents should be more authentic when expressed on the basis of DNA content. We previously attributed the decrease in the bound ascorbic acid content of certain organs to the decreased capacity of the proteins to bind ascorbic acid ${ }^{6}$. But in that work rats which had only just matured (10-14 weeks old) were compared with $50-60$ week old rats, and the results were expressed on the basis of wet weight. In this investigation, fully matured ( 30 week old) rats were compared with old (99 week old) rats.

Our earlier observations may not give the true change in bound ascorbic acid with increasing age, bccause this investigation suggests that the change found on the basis of wet weight may not represent true change. The estimation of bound ascorbic acid per cell may perhaps give a better picture.

This work was carried out during 1966 in the Zoology Laboratory, Cuttack.

Department of Biology,

B. K. Patnatk

Regional College of Education,

Bhubaneswar-1, Orissa, India.

Received March 8, 1968.

'Shock, N. W., Biology of Aging (edit. by Strehler, B. L.), 258 (Waverly Press. Baltimore, 1960).

2 Yiengst, M. J., Barrows, jun., C. H., and shock, N. W., J. Gerontol..14. + (1959).

s Barrows, jun., C. H., Yiengst, M. J., and shoek, N. W., J. Gerontol., 13. 351 (1958).

+ Kanungo, M. S., and Patnaik, B. K., Biochem. J., 90, 637 (1964).

- Patnaik, B. K., and Kanungo, M. S., Gerontologia, 10, 155 (1965).

- Patnaik, B. K., and Kanungo, M. S., Biochem. J., 100, 59 (1966).

Summerwell, W. N., and Sealock, R. R., J. Biol. Chem., 196, 753 (1952).

s Schneider, C., Methods in Enzymology (edit. by Colowick, S. P.. and Kaplan, N. O.), 3, 680 (Academic Press, London, 1957).

' Garret, H. E., Elementary Statistics, 94 (Longmans Green and Co., New York, 1956).

\section{Presence of Compounds containing Iron in the Digestive System}

Problems concernod with iron storage and its subsequent utilization by invertebrates have, most often, concentrated on those forms in which haemoglobin is present ${ }^{1-11}$ and in certain instances in those organisms in which haemocyanin is utilized as a respiratory pigment ${ }^{11}$. Reports have shown that when haemoglobin is utilized as a respiratory pigment it is demonstrable not only in the body fluid of the animal but also in a variety of tissues-muscle, nerve and eggs ${ }^{6}$, as well as fat cells ${ }^{12}$. In some cases, such as Daphnia magna which is actively. losing haemoglobin, porphyrins are not demonstrable, but loosely bound iron is easily demonstrated histologically in the walls of the gut caeca, in the fat cells and in the maxillary glands ${ }^{13}$. In certain organisms possessing the copper blood pigment haemocyanin it has also been possible to demonstrate the presence of iron porphyrin compounds (haemochromogens) not only in the blood but also in such diverse structures as the eggs of Limulus polyphemus, the radula muscle and heart of Busycon canaliculatum (both myoglobin and cytochrome being present), cytochromes in the heart, claw and skeletal muscle of Homarus americanus, and cytochromes in many of the tisssues of Loligo peali ${ }^{11}$. Conclusions drawn from these many experiments indicate that, except for the substitution of haemocyanin for haemoglobin, oxygen utilization is essentially the same as in mammals. They also point out that these animals are utilizing iron in the synthesis of certain porphyrin compounds of the cytochrome system. It has thus been fairly well established that possession of haemoglobin as a respiratory pigment is no prerequisite for tho presence of compounds containing iron in animal tissues.

Investigations in this laboratory have indicated that compounds containing iron are present in other crusta. ceans (certain Isopoda) which possess neither haemoglobin nor haemocyanin as a respiratory pigment. These compounds were first noticed during a histochemical study of the digestive system of the benthonic isopod, Bathynomus giganteus, a non-decapod malacostracan, representing a group in which haemoglobin is unknown and haemocyanin has only recently been reported in certain members ${ }^{14}$.

During the initial study, twelve animals, ranging in size from approximately 5 in. to 14 in., were examined. Col. lections were made in January during a US Bureau of Fisheries quadrant survey of the Gulf of Mexico. Depth of the collections varied from 170 to 300 or more fathoms. 